\title{
MEMORIES OF THE FLOOD OF 1974 AND THE PRODUCTION OF SPACE IN TUBARÃO (SC)
}

\author{
ASSUNÇÃO, Viviane Kraieski de ${ }^{\text {* }}$
}

(a) PhD in Social Anthropology. Professor University of Extremo Sul Catarinense (UNESC). ORCID ID: http://orcid.org/0000-0003-0118-2486. CURRICULUM LATTES: http://lattes.cnpq.br/3938314040854246

\section{(*) CORRESPONDING AUTHOR}

Address: UNESC, Avenida Universitária, 1105, Bloco P, Sala 13, Bairro Universitário, CEP: 88806-000, Criciúma (SC), Brasil. Tel: (+55 48) $3431-2595$ E-mail: vivianekraieski@gmail.com

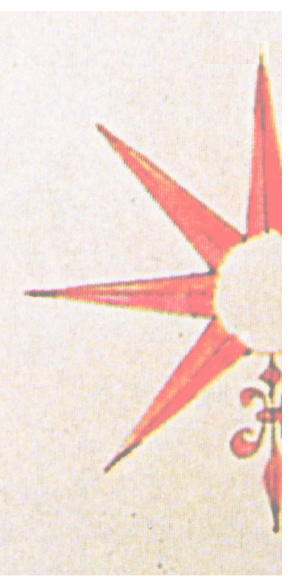

\section{ABSTRACT}

The flood of 1974 displaced 60,000 of the 70,000 inhabitants and caused the deaths of dozens of people of the municipality of Tubarão (SC). The city has kept the memory of the flood through several initiatives, which have intensified in the early 21 st century. From the perspective that disaster investigations should take into account not only their contingency, but also post-catastrophe studies, a document research about the politics of memory of the flood of 1974 was carried out. The research aim at understanding these actions as politics of memory and investigating their relation with the social production of urban space through analysis of the monuments in the city and the adoption of other measures, such as the institution of the day of remembrance of the catastrophe. The research demonstrates that these monuments and references to the flood present close relation to moments and political personages of the city, and concludes that these policies are key elements for the construction of the urban history and identity and legitimation of new political actions.

Keywords: Flood; Memory; Social production of space; Monuments.

\section{RESUMO / RESUMEN}

\section{MEMÓRIAS DA ENCHENTE DE 1974 E PRODUÇÃO DO ESPAÇO EM TUBARÃO (SC)}

A enchente de 1974 desalojou 60 mil dos 70 mil habitantes do município de Tubarão (SC) e provocou a morte de dezenas de pessoas. A cidade mantém a memória da enchente por meio de diversas iniciativas, intensificadas no início do século XXI. Partindo da perspectiva de que as investigações sobre desastres devem considerar não apenas sua contingência, como também incluir estudos pós-catástrofe, realizou-se uma pesquisa documental sobre estas iniciativas de manter a memória da enchente. O objetivo foi compreender estas ações como políticas de memória e investigar suas relações com a produção social do espaço urbano, por meio da análise dos monumentos na cidade e da adoção de medidas como a instituição do dia municipal de memória da catástrofe. A pesquisa demonstra que a construção de monumentos e outras referências à enchente apresenta estreita relação com momentos e personagens políticos do município, e conclui que as políticas de memória são elementos chaves à construção da história e identidade urbana e legitimação de novas ações políticas.

Palavras-chave: Enchente; Memória; Produção social do espaço; Monumentos.

\section{MEMORIAS DE LA LLENA DE 1974 Y PRODUCCIÓN DEL ESPACIO EN TUBARÃO (SC)}

La inundación de 1974 desalojó 60 mil de los 70 mil habitantes del municipio de Tubarão (SC) y provocó la muerte de decenas de personas. La ciudad mantiene la memoria de la inundación por medio de diversas iniciativas, que se intensificaron a principios del siglo XXI. Partiendo de la perspectiva de que las investigaciones sobre desastres deben considerar no sólo su contingencia, como también incluir estudios post-catástrofe, se realizó una investigación documental sobre las iniciativas de mantener la memoria de la inundación. El objetivo de la investigación es comprender estas acciones como políticas de memoria y investigar sus relaciones con la producción social del espacio urbano por medio del análisis del proceso de construcción de monumentos en la ciudad y de la adopción de otras medidas, como la institución del día de memoria de la catástrofe. La investigación demuestra que los monumentos y otras referencias a la inundación presentan relación con momentos y personajes políticos de la ciudad y concluye que las políticas de memoria son elementos claves para la construcción de la historia y identidad urbana y la legitimación de nuevas acciones políticas.

Palabras clave: Inundación; Memoria; Producción social del espacio; Monumentos. 


\section{INTRODUCTION}

The environmental historian Christof Mauch, in the introduction of the book Natural Disasters, Cultural Responses,organized together with the historian Cristian Pfister, states that the memory of a natural disaster tends to be of short duration, unlike the memories of war that last for a long time. In the case of floods, when the waters return to normal levels, the disaster ceases to be news in the media, which contributes to its oblivion. According to the author, the memories of a war, unlike the memories of a natural disaster, are maintained by the existence of organizations such as those for veterans, and there is the construction of memorials in honor of the victims in the world (MAUCH, 2009).

In the case of the 1974 flood in the municipality of Tubarão, located in the south of the State of Santa Catarina, Mauch's conclusions cannot be confirmed. Memories of the flood are still present in residents' accounts - both those who experienced the disaster and those who did not live in the city during the flood or who were born in the subsequent years. The city maintains the memory of the flood through several initiatives, which have been taking place since the beginning of the 1980s, but intensified at the beginning of the twenty-first century.

Although a disaster is generally perceived by the subjects as a temporally limited event (VIGH, 2008), some scholars, such as Oliver-Smith (1999), consider the importance of analyzing it as a process. In this sense, disaster research should take into account not only its contingency, but must also include post-disaster studies (OLIVER-SMITH, 1999; SMITH, 2012). Ullberg (2016) argues that post-catastrophe is a cultural and political process that confers an interpretation to a critical event of the past, unfolding in time and space. This process can be considered as memory (ULLBERG, 2016).

Following this perspective, documentary research was carried out with the objective of identifying the policies of memory of the flood of 1974 and analyzing their relationship to the social construction of the space of the municipality of Tubarão. These policies of memory can encompass a range of practices and actions developed by social actors and institutions that seek to build and maintain the memory of the disaster. Memory is a dynamic and selective process of what is to be remembered or forgotten (WOORTMANN, 2000), and its continuity may also encompass re-significations of the event and its consequences. In this sense, the politics of memory can involve different, and sometimes divergent, intentions and interests, according to the perspective of the social actors and institutions involved.

It is understood that memories of the flood are spatially integrated into the landscapes that serve as evocations and play a central role in the construction of places. In this way, memory is integrated into space in a form that can be materialized or objectified and is invoked through things and objects that have a symbolic role (ULLBERG, 2016). This article analyzes the process of the construction of monuments and other references to the flood of 1974 since the 1980s in Tubarão, such as the institution of the Municipal Day of the Remembrance of the Catastrophe. These are initiatives by political groups and municipal institutions to produce and maintain the memory of the disaster. These actions are linked to a process of construction of history and urban identity, which are used to legitimize new political actions in the municipality.

\section{METHODOLOGICAL PROCEDURES}

Memory is the methodological foundation of this research, considered here in its collective and social character: "A man, in order to evoke his own past, often has to appeal to the memories of others. they refer to reference points that exist outside of him, and which are fixed by society" (HALBWACHS, 1990, p.54). Memory represents more than a recollection, for it is also an action that can contribute to the transformation of the life of individuals and social groups (BOSI, 1998). 
Memory is not limited to memories of what has been lived in the past. In Woortmann's words (2000: 213), "memory operates in the sense of "working" the past to forge the present and build the future, and this can be done both through remembrance or forgetfulness." Thus, both the said and the unsaid are fundamental in this construction of the present and the future. Memory acts in a selective manner, as it makes certain events or (or fragments of events) present to the detriment of others, to which may be attributed different meanings according to time and space" (WOORTMANN, 2000).

In order to obtain data on the construction of monuments and other initiatives created to produce the memory of the flood, the research used documentary sources. An analysis was carried out of the news about the flood of 1974 and the works carried out to prevent new floods in Tubarão, published between 1974 and 1983 in the local newspapers Tribuna Sulina, Nosso Jornal, Jornal da Cidade, Imprensa do Sul, Folha da Semana and Jornal do Sul, in state circulation newspapers in the State of Santa Catarina A Gazeta, O Estado, Diário Catarinense, and Jornal de Santa Catarina, besides the Correio do Povo (from Porto Alegre) and the national circulation magazines Veja and Fatos e Fotos. Some of these sources were found in collections of news clippings about the flood compiled by the Tubarão Municipal Historical Archive, which are available for consultation on site.

Also included in the corpus of the research was news on the same themes published in the local newspapers Diário do Sul, Sul em Foco and NotiSul, from 2004 to 2015. The temporal cuts 1974-1983 and 2004-2015 - were established as the periods related to the dredging and straightening works of the Tubarão River and the inauguration of monuments and other initiatives previously identified by the research. Bibliographical research was also carried out, through consultation in written works on the history of the municipality and memories of the 1974 flood, such as Albeirice (1981), Cargnin (2000), Feuerschuette (2004), Machado (2005) and Vettoretti (1992).

By using newspapers and magazines printed as sources of historical knowledge, it is considered that the performance of these vehicles does not occur impartially, because they are immersed in the political-ideological field. In this way, these media not only make neutral records of events, but also "filter" and organize these events, denoting intentionality (ZICMAN, 1985). Their use in this research is not, therefore, associated with attesting "truthful" facts, but aims to recover records on the construction of monuments and the forms that significance was attributed to them, without considering these discourses as unique or homogeneous.

\section{FLOOD OF 1974}

The flood of 1974 was widely reported by the local and national press. In the Public Historical Archive of the municipality of Tubarão, it is possible to find news of the disaster compiled in notebooks, which were the sources of this research. At least five books on the flood have been published, both of memories and of studies carried out from different perspectives, as well as academic papers.

According to these sources, the 1974 flood was not the first flood to strike the municipality of Tubarão. The local press had recorded floods caused by the overflow of the Tubarão river since the foundation of the municipality in the nineteenth century. Freitas (2001: 12), referring to a flood that occurred in 1887, states that "the inhabitants of the city were already accustomed to seeing floods and knew that the waters would not exceed a certain level". A similar perspective is presented by the historian Amadio Vettoretti (1992, 225), who concludes that the inhabitants "had lost the memory of previous floods, because in the last decades, they only happened in the fields".

Freitas (2001) states that in the three decades prior to the 1974 flood, floods occurred frequently and at any time of the year due to rainfall and mainly affected agricultural production. As they were limited to rural areas, the population was ignorant about these floods, which would explain the fact that many people considered the flood of 1974 "as a phenomenon, something unheard of, and for some, even a punishment." (VETTORETTI 1992, 224). 
Predominantly affecting the areas farther from the center of Tubarão, the floods that occurred before the year 1974 did not prevent the occupation of the city from spreading to the areas near the river that crosses the municipality. The Tubarão River crosses the city center (Figure 1), where most of the commercial establishments in the municipality are located and housing is economically highly valued by the real estate market.

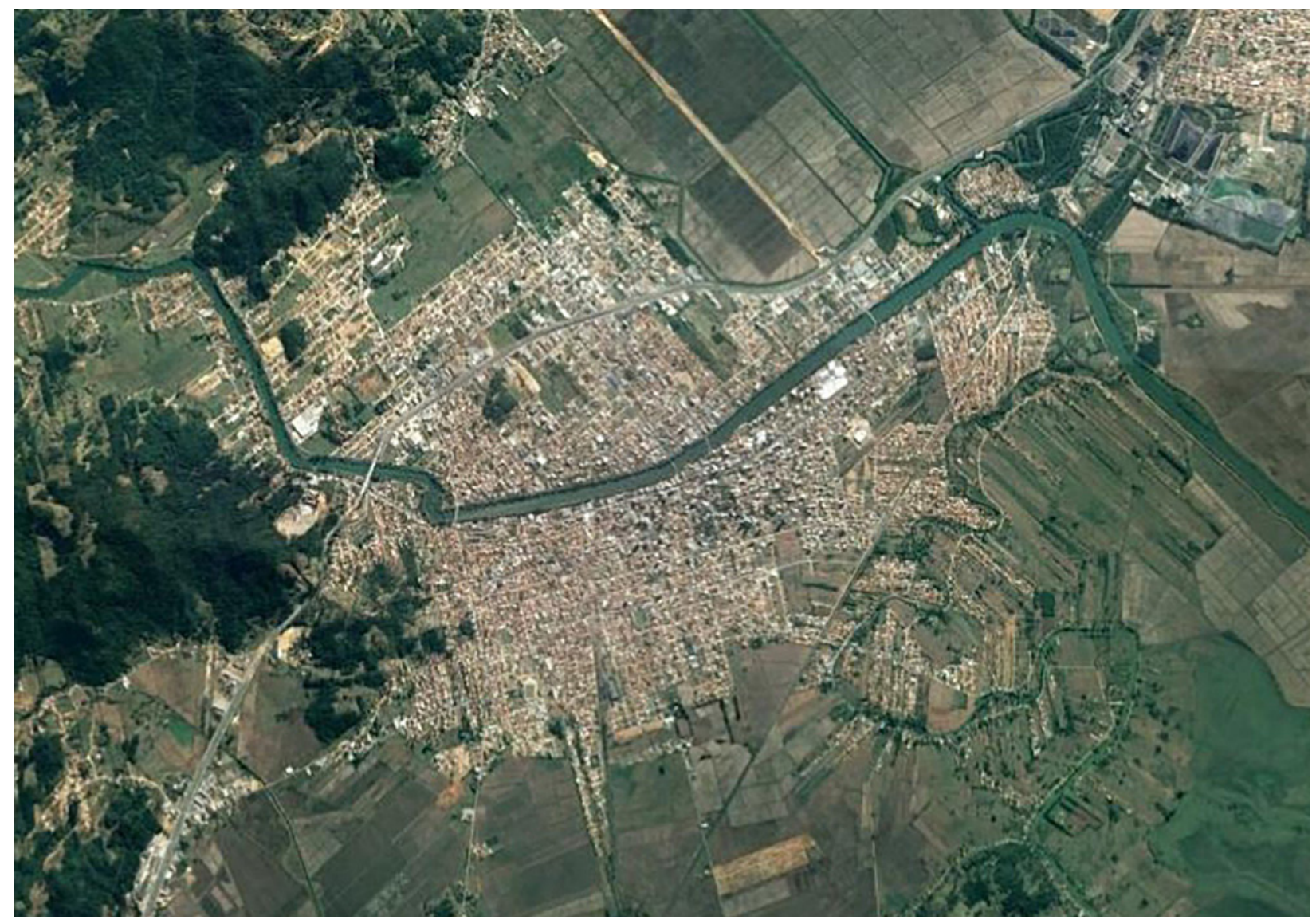

Figure 1 - Aerial view of the city of Tubarão

Source: Google Earth, 2016

In 1974, heavy rains on Friday, March 22, and Saturday, March 23, had already flooded the lower regions of the municipality, which were already on alert. According to the authors, the flood was caused by a combination of several factors: prolonged rainfall since the beginning of March of the same year, which led to the saturation of the soil, along with the rains and winds from the coast, a phenomenon known locally as the lestada that had caused the damming of the river waters of the Serra Geral mountain range. The sedimentation of the river and the high tide, during the same period, would also have hindered the flow of the water to the sea (VETTORETTI, 1992; CARGNIN, 2000) (ASSUNÇÃO, 2014, p.197).

The Tubarão Community Military Command (FCTC) had forbidden the radio station in Tubarão from broadcasting the first information on the floods, which initially reached the lower and peripheral regions of the municipality, so that there would be no panic. According to a note issued by the FCTC at the time, all news should be previously authorized by the military command, and recommended that the programming should be filled with "light music" (CARGNIN, 2000). Some sources attribute the deaths to the residents' lack of information as they were unaware of the gravity of the situation.

After the waters subsided, the military intervened in the municipality with the creation of the Military Command of the Garrison of Tubarão, under the command of Major Varella. The flood led many residents to shelter on the roofs of houses or in neighboring buildings. There were also landslides, such as on the Morro do Caruru, which caused 25 deaths - a number that, according to 
reports from residents affected by the flood, was much higher. Rescue and the delivery of food shipments were made by helicopter and Fire Department boats. The destruction caused by the strong current was documented by the press, which came to portray Tubarão as "the city that drowned to death" "and that "seemed to be crossed off the map". ${ }^{2}$ News and reports from residents describe the destruction of homes, streets, railroad tracks and the interruption of the power supply and telephone services. The death toll is still disputed.

According to official data, the 1974 flood caused the deaths of 199 people and displaced 60,000 of the 70,000 inhabitants of the city of Tubarão at the time. The death toll, however, is disputed by the residents who lived through the flood. The press had reported during the flood that the death toll would be in the thousands. Some residents affirm the existence of common graves to bury bodies and a high number of missing persons. (ASSUNÇÃO, 2014, p. 197-198)

This information can also be found in reports published by the press at the time, as in this excerpt from a report published in the magazine Veja, dated April 3, 1974: "The dead were buried quickly in mass graves and the stench spread the panic of air-borne epidemics. The corpses were no longer being identified and there was a growing certainty that the victims could be over a thousand, even 4,000 or 5,000." 3 The existence of only one common grave, opened at the rear of the city's central cemetery, was documented by reports published in the printed newspapers of the time. Feurschuette, mayor of Tubarão at the time of the flood, also admitted in his book about the disaster that they reached the "absurdity of announcing 8,000 deaths" (2004, 47). It was also frequently reported in the press after the flood that part of the population was leaving the city, which motivated calls in several newspapers for the residents to remain in the municipality.

\section{THE INTERRELATIONSHIP BETWEEN SPACE AND MEMORY}

As Ullberg (2016, pp. 25-26) proposes, memorials designed to remember big atrocities seem to be a modern genre, as they are found all over the world, such as the Berlin Holocaust Memorial, the Peace Memorial Museum in Hiroshima, the memorial built on Ground Zero, in honor of the victims of the terrorist attack on the World Trade Center, in New York, among others. Similarly, memorials are built in remembrance of natural catastrophes, such as the Tsunami Museum in Aceh, the Indian Ocean Tsunami Memorial in London, and the memorials to the victims of Katrina in New Orleans. Official and unofficial places coexist, like those created in memory of the fire in a nightclub in Buenos Aires in 2004. Survivors and families of the victims created a shrine with works of art and symbolic images, while the local government built the Memorial Square in honor of the victims. In order to understand and problematize the construction of these places and later to analyze the monuments and other initiatives related to the memories of the 1974 flood in Tubarão, initially there is an analysis of the relationship between memory and the social construction of space.

According to Ullberg (2016, p.19), some authors differentiate three coexisting modes of memory function. The evocation would be equivalent to what Aristotle calls mneme, the memory that comes without effort, through lived experiences and memories of places and people. The Aristotelian notion anamnesis, or amnesia, refers to something that will be forgotten if no effort is made or if there is

(1) The city that drowned to death. O Cruzeiro, 17 April 1974, Collection of news on the flood of 1974 of the Historical Archive of the Municipality of Tubarão.

(2) Tubarão after the catastrophe. Correio do Povo, Porto Alegre, March 21. 1976, Collection of news on the flood of 1974 of the Historical Archive of the Municipality of Tubarão.

(3) Hunger, Death and Destruction. Veja, 03 April. 1974, Collection of news on the flood of 1974 of the Historical Archive of the Municipality of Tubarão. 
no wish to remember it. Amnesia can be related to two forms: commemoration and reminiscence. The latter refers to the effort to remember something that may take place, during a conversation, for example. Celebration would require a ritual remembrance, usually held in a public space, such as the activities that occur as a result of the institution of the Municipal Day of Remembrance of the Catastrophe of 1974, in the municipality of Tubarão, which will be described later.

Using Geertz's conceptions, Ullberg (2016) points out that there are spatial dimensions in and for memory. While the dimensions for memory indicate behavioral models, the dimensions of memory supply the symbolic representation for these models.

In this sense, space is understood as a set of contents and forms, or objects and actions, as conceived by Milton Santos (1997), who defines its existence from its uses and meanings, that is, from its material and social dimensions. Also adopting a multidimensional perspective, Lefebvre (1972) defines that space is formed by three dimensions, the perceived, the conceived and the lived, which participate in the logic of the social production of space and are associated with representations. Thus, in studying the history of a space, one must also consider the history of its representations, as well as its link with practice and ideology.

The flood-related monuments can be considered "places of memory", a concept created by the French historian Pierre Norra. The author problematizes the increasing creation of these places, stating that they originate from the perception that archives need to be created, since the survival of spontaneous memory is threatened by the acceleration of history, resulting from the processes of globalization, mediatization and massification. In Nora's words, "if we truly lived the memories involved, they would be useless" (1993: 13). The places of memory necessarily have three meanings, in different degrees: material, functional and symbolic (NORA, 1993).

For Pollak (1989), there is a collective operation that operates in the sense of transforming social facts into "things." Therefore, one must analyze "how and by whom they are solidified and endowed with duration and stability" (POLLAK, 1989, pp. 3-15). Memory provides references to the past, acting to maintain the cohesion of groups and social institutions of a given society. In this "framing" of memory, subjects legitimized by institutions or by their peers collaborate as guardians of these memories. Here, one can make a relationship with the founding of the Historical Archive of Tubarão in 1990, where periodicals, images and other documents related to the flood of 1974 and other events of the municipality of Tubarão can be found. This group cohesion from a past referential also contributes to the construction of an identity process. "What is at stake in memory is also the sense of individual and group identity" (POLLAK, 1989, pp. 13-15). In this way, places of remembrance are "signs of recognition and belonging to a group" (NORA, 1993, p.13).

In the municipality of Tubarão, several places of memory of the flood of 1974 were constructed. Most of the spaces referred to herein are monuments. These articulate the dimensions of space and time, because "they offer the possibility of a spatial reference, through perception, and a temporal reference, through the path of memory" (Freire 1997: 41). This reference of the monument to memory is in the etymology of the word, originating from the Latin verb monere, which means to remind (FREIRE, 1997). In this sense, it can be affirmed that monuments participate in the "theatricalizing" of social values by acting to maintain the collective memory beyond the finiteness of the temporality of daily life (JEUDY, 1990, p.10).

These monuments are, for the most part, state sponsored. More than objects with aesthetic functions, they have intentional political meanings (CORREAA, 2005). They can also be considered as regulatory mechanisms of the sense of a past event (ROWNTREE; CONLEY, 1980), and, through their ideological content, model the social imaginary (PEET, 1996). However, it should be pointed out that monuments, like images, can be "read" in different ways by social actors, generating diverse and divergent interpretations (DANIELS; COSGROVE, 1993).

Next, the monuments and other places of memory of the 1974 flood in the city of Tubarão are presented, seeking to understand their construction processes and how they contribute to the social production of space. 


\section{MARKS AND MONUMENTS OF THE FLOOD}

Currently, in the municipality of Tubarão, there are at least two records of the level reached by the flood waters of 1974, both marked by plaques giving the information. One of them is in front of the Ótica Zumblick, owned by a traditional family of the municipality. Willy Zumblick, the owner of the establishment, was a well-known artist of the State of Santa Catarina. He and his brother, Walter Zumblick, held political positions in the municipality. Among the hundreds of canvases of oil paintings he produced throughout his 94 years of existence, Willy devoted two to the memories of the flood, produced in the year of the disaster. The work Migrants of the Flood portrays the subjects carrying their belongings, leaving the city during the disaster. The other, entitled The Scourged of the Flood, shows the subjects in the water, seeking help and the image of a helicopter, which had been used to bring food and rescue people.

The other register of the marks of the level reached by the flood is on the wall of the water pump of the warehouses that belonged to a tobacco company in the municipality. Currently, the city's only shopping mall is built in the same spot and the plaque has been maintained near the back gate.

These records of the flood levels occur in other contexts, providing possibilities of comparison between subsequent events. Pfister (2011) suggests that these signs do not just have a communicative purpose. They can also be read as visual expressions of a memory of risk, which suggests the probabilities of loss in the event of a new occurrence or even a warning for the future.

\section{TOWER OF GRATITUDE}

The Tower of Gratitude (Figure 2), inaugurated in 1983, was built next to the municipality's Cathedral as a form of thanks for the donations received by the city after the flood. The Cathedral is located in a higher part of the city, popularly known as Morro da Catedral, and during the flood it served as a shelter for hundreds of affected people. The churchyard was also used as a landing pad for the helicopter that delivered food and relief to the victims.

In the newspaper O Estado, March 23, 1975, which featured a special edition entitled Tubarão, one year later, there is information that the city intended to build a monument named after "the dead and the benefactors of the flood". This was Willy Zumblick's initiative, the secretary of Tourism of the municipality at the time, who intended the work to be "very simple, without refinements, appropriate to a convalescent city". Still according to the news report, opinions in the city at the time were divided: some supported it, by considering it valid, "but unnecessary, if it will be put into practice immediately." Others "find the idea, as well as valid, absolutely necessary, "because the victims of the flood must be remembered".' 4 A report published in a local newspaper in the year 1982 informed that the side walls of the belfry have panels by the artist Willy Zumblick that, in addition to a religious representation, bring images "remembering scenes of the flood and of the help given". 5

On one side of the belfry (Figure 3), there are plaques naming the people responsible for the planning, financing and execution of the work, which include the Catholic Church and businessmen of the municipality, as well as state and municipal governments. The central plaque has the following words: "REBUILDING IS LIVING. The people of the city of Tubarão, SC, Scourged by the Catastrophe of the Flood of March 1974, thank the expressions of support, donations and services rendered, received from everyone and everywhere. Signed The People of Tubarão”.

In these words, it is important to emphasize that in addition to thanking those who made donations and rendered services to the flood victims, emphasis is given to the phrase "Rebuilding is living", which was one of the slogans used in posters distributed by the municipality after the flood as a way of motivating the population to recover the city (VETTORETTI, 1992).

(4) Tubarão, one year later. O Estado, Florianópolis, March 23. 1974, Collection of news on the flood of 1974 in the Historical Archive of Municipal Tubarão.

(5) Cathedral Tower is completed in October. Jornal da Cidade, Tubarão, 23 Jul. 1982. p. 05 
The word "scourged", also present on the plaque and frequently used by the press at the time to portray those affected by the disaster, denotes the meaning of suffering and precarious living conditions. Lopes (2015, p 123) analyzes that the meaning given to the word scourged changed in the post-flood period: unlike the rural individual, portrayed as "affected", "the scourged was not the individual who received the flagellum, the suffering, but rather the one who could receive help from all parts of the country and organized by the ruling classes". The researcher also observes that the word scourged, together with exodus, solidarity and reconstruction, were widely used by the press at the time, which was engaged in the campaign to collect donations (LOPES, 2015, page 123).

In the monument, this meaning is linked to biblical Christian images, whose representations are present in the panels that appear above the informative plaques.
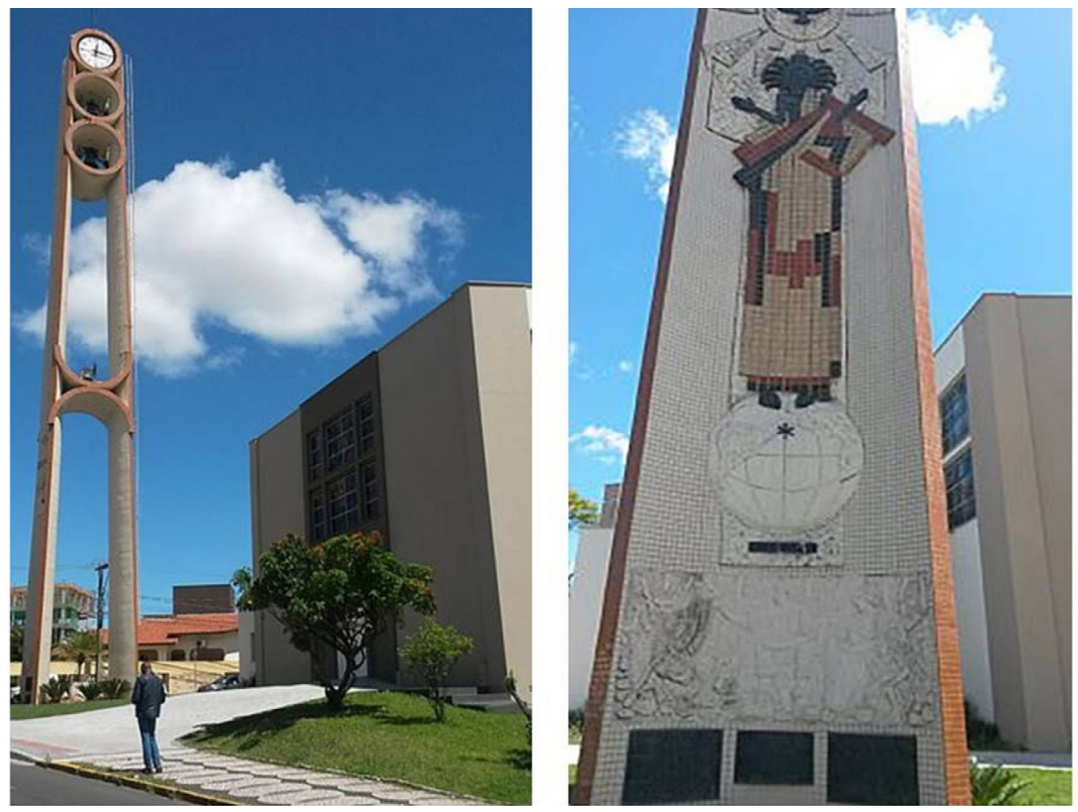

Figure 2 - Tower of Gratitude (front and side view)

Source: Author

\section{MONUMENTALIZATION OF THE FLOATING DREDGER}

The book that tells the story of Tubarão's Chamber of Commerce (CDL), states that in 1978 the association received a letter from the then Congressman Adhemar Guisi warning about the promulgation by the Presidency of the Republic of Decree No. 81,611 of 23 of June, authorizing the expropriation of 27 million square meters of land in the municipalities of Tubarão and Laguna for the works of straightening and widening of the Tubarão River. It was understood that the meandering route of the river contributed to the flood, causing the retention of water in some localities (CDL, 2016).

The dredging and straightening work was completed in 1983 by DNOS (National Department of Sanitation Works), a body linked to the Interior Ministry, which was abolished in 1990, at the beginning of Fernando Collor's administration. In 1978, DNOS designed a flood prevention plan for the Tubarão river. In addition to the dredging and straightening of the river, which were carried out, it was also planned to build three dams to contain floods, which were never constructed. The three dams would cost ten times more than the straightening that increased the Tubarão River's flow from 400 cubic meters per second to 2100 cubic meters per second, reducing the risk of a new "catastrophic flood" by $60 \%{ }^{6}$

At the end of the dredging and straightening of the Tubarão river, part of one of the floating dredgers used in the works was painted and placed in the Orlando Francalacci Square, which is on the riverbank in the center of the city. The inauguration of the works was carried out in the city

(6) DNOS passes on resources to eleven municipalities in the South. Jornal da Cidade, Tubarão, 23 Jul. 1982. 
with the presence of the then Minister of the Interior, Mário Andreazza, besides the governor, the candidate for governor, the General Director of DNOS and the Director of DNOS of Santa Catarina. On the same day, there was a rally of the PDS (Social Democratic Party). ${ }^{7}$

The inauguration took place at a strategic time for local politics, one month before the elections for the city hall and the state government. The direct elections marked the political reopening during the government of the president João Figueiredo. In the municipality of Tubarão, ten candidates fought for the city hall, but the election was polarized between the candidate of the PDS, which replaced ARENA, the political party that supported the military regime, and the candidate of the PMDB, which represented the opposition to the regime.

During the inauguration ceremony, Andreazza declared that "the performance and continuity of this work depends on the victory of the PDS, the victory that President Figueiredo needs to maintain the current political process". According to the mayor of Tubarão at the time, the work "relieves the concern of the tubaronense regarding other floods". ${ }^{8}$ A report in the Tribuna Sulina newspaper says that the work eliminates "once and for all the ghost of the flood, including the lamentable memory". ${ }^{9}$ The election, held on November 15 of the same year, was won by the opposition candidate. Vettoretti (1992, p.107) characterizes this election as historical, "because it was the first time that the opposition, properly speaking, won in Tubarão."

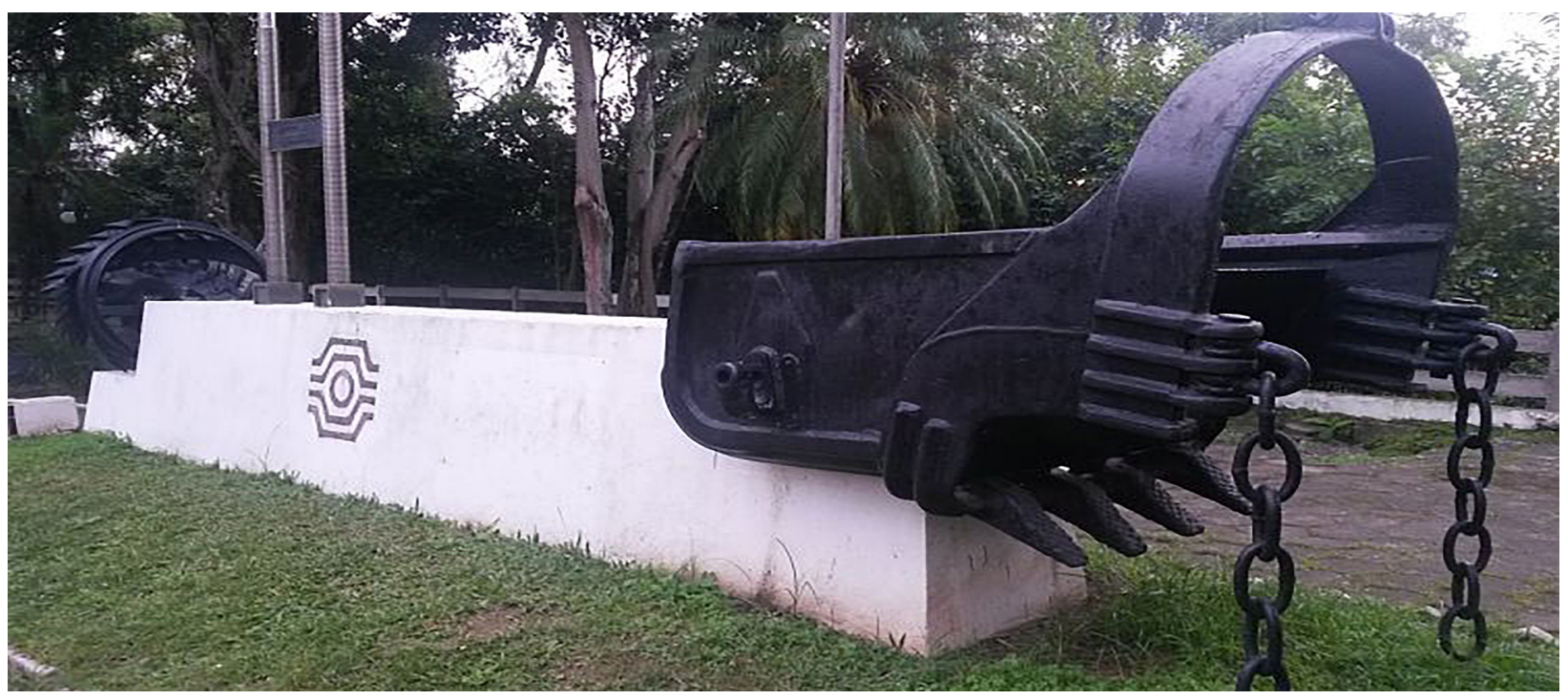

Figure 3 - Floating dredger

Source: Author

\section{MONUMENT IN HONOR OF THE VICTIMS}

In Orlando Francalacci Square, located in the center of the city, a monument "To the Victims of the Flood of 74" was erected in remembrance of the 30 years of the disaster. The stone flower with its buds symbolizes the rebirth of the city after the catastrophe. The plaque indicates that the 1974 flood was the "most terrible catastrophe ever recorded in national history". The victims "are remembered as symbols of the struggle of the citizens of Santa Catarina, who through their grit have demonstrated the union of the people, transforming pain into a strength capable of rebuilding the municipality and solidifying the foundations of a just and egalitarian nation."

The inauguration of the monument occurred during the event "Floods of 74, Tubarão, 30 years later! "According to newspaper reports, ${ }^{10}$ the objective of the event was to show what the city lived

(7) Andreazza and Córdova inaugurate dredging works. Jornal da Cidade, Tubarão, Oct. 15. 1982.

(8) Andreazza inaugurates dredging and asks for a vote for the PDS. Jornal da Cidade, Tubarão, Oct. 15. 1982.

(9) River works will be inaugurated. Tribuna Sulina, Tubarão, Oct. 16, 1982.

(10) Commission organizes event about 1974. Diário do Sul, Tubarão, Mar 11. 2004, p. 03. Flood will be remembered. Diário do Sul, Tubarão, Mar 09. 2004. Commendation of Gratitude is delivered. Diário do Sul, Tubarão, Mar 24. 2004, p. 02. TB: real chances of flooding. Diário do Sul, Tubarão, Mar 24. 2004, p. 03. 
through in those days to the new generations, as well as the causes, effects and transformations that occurred in the municipality after the flood, preventing a new disaster. In addition to the inauguration of the monument, a book was published about the disaster by the mayor of Tubarão at the time of the flood, and the Commendation of Gratitude was awarded to the mayor, the congressman and the governor and senator of Santa Catarina during the period of the flood, besides the then director of the DNOS.

At the Municipal Cultural Center of Tubarão, which also houses the Willy Zumblick Museum, there is a permanent exhibition of photographs taken during the 1974 flood by the photographer Ingo Penz. The collection was acquired by the municipal government in 2004, 30 years after the flood. A work order was also signed by the mayor to erect and carry out works to curve the structure of the Manoel Cascaes Bridge, in the Morrotes neighborhood, which had a straight structure, encouraging the damming of the waters of the river.

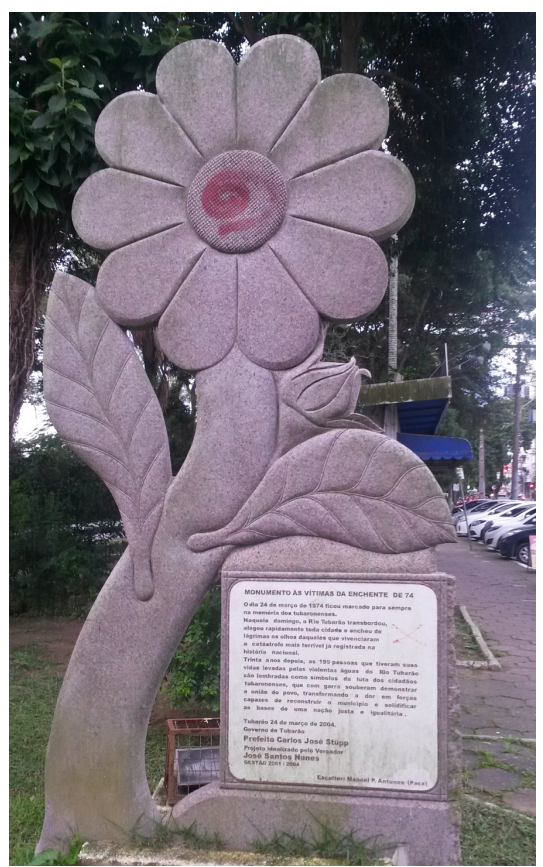

Figure 4 - Monument in honor of the victims Source: Author

\section{INSTITUTIONALIZATION OF REMEMBRANCE DAY}

In 2009, the Municipal Day of Remembrance of the Catastrophe of 1974 - Law n 3 ,289, of May 12, 2009 was instituted. In addition to determining March 24 as a day of remembrance of the flood, it also provided for the intensification of mobilization for the prevention and efficient response to other possible natural disasters. The law defined natural disasters as "floods, gales and or inclement weather". Also according to the wording of the law, the municipal public authorities should promote, through the Civil Defense, "conditions for all tubaronenses to participate in events and studies, with the purpose of remembering the tragedy of 1974 and reviewing what is being done by the Public Power and by the citizens to minimize the effects of a possible natural disaster" (TUBARÃO, 2009).

The law also foresees that, on March 24, at 3:00 p.m., the bells be rung in a measured manner, and that the people stop their activities for one minute. It also establishes the obligation to promote in public and private schools of the municipality, at all levels of education, "acts that recall the 1974 catastrophe and forms of prevention and efficient response to other possible natural disasters." Churches, "independent of religious creed", are also encouraged to promote reflections on the theme on that day (TUBARÃO, 2009). 
As presented by Theis (1999), establishing these dates to remember an event points to a problematization of the space-time relationship. According to the author, these recollections "take" the event from the past, projecting contemporaneity, and, in this way, promote a questioning about time and distance. In the words of Silva (2002), "the celebration aims to demonstrate, [...] that the event "remembered", for its symbolic value, can refer to the time to come.

Similarly, Jelin (2002) states that the acts of commemoration and remembrance are focused not only on the present, but also on the future, since the activities may contain pedagogical functions for successive generations. These ceremonies should be understood as dynamic rituals, which present changes in each annual cycle, as they reflect and reiterate the continuity of both identity and meaning, as well as changes and transformations in the ways in which celebrations are signified and practiced (PIPER, 2009).

\section{MEMORIES AND PUBLIC POLICIES}

Since 1974, the municipality of Tubarão has not been hit by a flood of the same proportions. In this period, however, floods reached the rural and lower areas, located in the periphery of the municipality, but did not reach the downtown and the main districts of the city. The last flood, in May 2010, was reported in local newspapers as a risk to the municipality, which could repeat the 1974 disaster. It is worth mentioning that the aforementioned plaques and monuments are located in the center of the city, mostly occupied by middle and upper-class families. In other locations, such as Morro do Caruru, where a landslide killed 25 residents during the 1974 flood, there is no reference to the victims or the disaster. In societies where social classes are spatially located, causing neighborhoods and localities to be identified with a particular social level or status (OLELHO, 2002), space - the objects and actions that constitute it - cannot be considered neutral in relation to these hierarchies (SANTOS, 1997).

The occurrence of a disaster, as analyzed by Sedrez (2013), has repercussions for public policies, since they reflect "specific social tensions" of a certain time and space. In the post-disaster period, political leaders are urged to respond to their causes and consequences, and to identify solutions for the future. In this sense, the historian concludes that the construction of the memory of disasters and the way they are remembered, together with their representative images, are fundamental for the definition of public policies.

The first two monuments built in Tubarão in remembrance of the flood were inaugurated in 1983, during a period of political disputes at the municipal and state levels, which were linked to the last government of the Brazilian military period. Since the 1974 flood, the press has reported on the efforts of politicians in the city and the southern region of the state to get the attention of the state and federal government for the reconstruction of the city and the construction of flood prevention works. In some post-flood headlines, one can note the emphasis on the names of politicians: "[Governor of Santa Catarina] Colombo manages resources to hasten reconstruction"; 11 "[President] Geisel receives [Senator] Konder Reis and [Mayor of Tubarão] Irmoto, to find out what South needs"; 12 " Thirty days later, Irmoto will be with Geisel"; "13 "Geisel gives order favoring the South." 14 Although there were frequent reports in the press that the state and federal governments were engaged in rebuilding the city, they "came up against social problems created or fueled by the flood, like the most affected neighborhoods being working class ones." (LOPES, 2015, pp. 124).

(11) Colombo manages resources to hasten reconstruction. Jornal de Santa Catarina, Florianópolis, Apr 20. 1974, Collection of news on the flood of 1974 of the Historical Archive of Municipal Tubarão.

(12) Geisel receives Konder Reis and Irmoto, to know what South needs. Jornal de Santa Catarina, Florianópolis, Apr 14. 1974, Collection of news on the flood of 1974 of the Historical Archive of Municipal Tubarão.

(13) Thirty days later, Irmoto will be with Geisel. O Estado, Florianópolis, Apr 24. 1974, Collection of news on the flood of 1974 of the Historical Archive of Municipal Tubarão.

(14) Geisel gives order to the South. Jornal de Santa Catarina, Florianópolis, Apr 30. 1974, Collection of news on the flood of 1974 of the Historical Archive of Municipal Tubarão. 
At other times, the newspapers also reported the wait for financial resources for the recovery of the municipality and for works to prevent new floods. An example is the report titled "Tubarão still does not sleep soundly". The text states that, seven years after the disaster, the people of Tubarão are "afraid of a possible repetition of the tragedy and ask about of the fate of money sent by the government and philanthropic entities." 15 The item refers to other reports published by the newspaper itself and other local newspapers regarding the release of funds by the federal government and cash donations, which are presented under the subheading "Only Promises". According to Albeirice (1981), the municipal government received CR \$ 16,319,326.79 from federal, state and anonymous donations, which represented approximately 52,305 minimum wages (FRASSON, 2011, p.26). ${ }^{16}$ In the words of Vettoretti,

Despite the fact that it received some non-refundable money, Tubarão lost the great opportunity, the great moment, after the flood, when the leaders failed to exploit the sensibility that had been declared by the heads of the Federal and State Government (VETTORETTI, 1992, 244).

The author mentions that during the "dramatic period" five ministers visited the municipality, and president Ernesto Geisel received the mayor of Tubarão at the time. Vettoretti cites some examples of works that he believes could have been carried out by sensitizing political authorities, such as the construction of a road bridge, asphalting and extending streets, as well as a project to occupy higher places in the city (VETTORETTI, 1992, pp. 244-245).

Thus the monuments present answers to the demands and suspicions related to the non-fulfillment of the promises made by political leaders soon after the disaster. They are linked to other institutions and influential subjects of the history of the municipality: while the Tower of Gratitude was built by the Catholic Church in partnership with businessmen, the monumentalization of the floating dredger marked the inauguration of a work by the government of President Figueiredo and his political allies. The other works planned by DNOS were never carried out.

The monument that marks the 30 years of the flood, as well as other initiatives, such as the institution of the Day of Remembrance of the Catastrophe, are also fruits of efforts by the municipal government, which recall and reinforce the performance of some political figures, such as the mayor and the major of the military command that controlled the municipality for a few days after the flood. In this way, it can be affirmed that these initiatives of construction and maintenance of the memory of the flood, which are materialized in the form of monuments in the city's downtown, have political, economic and social biases. In addition, this memory constitutes the process of building the municipality's identity and is triggered to validate actions, such as flood prevention works.

\section{URBAN IDENTITY AND THE LEGITIMIZATION OF NEW POLITICAL ACTIONS}

As Lopes (2015, p 235) states, the municipality of Tubarão "internalized the flood of 1974 in its history". This relationship between the flood and history can be perceived in the works giving the historical facts of the municipality (for example, VETTORETTI, 1992). According to the historian, "the maintenance of the collective memory is intended to maintain the idea of collective victimization, when the flood put them all in the position of victims, and affirm the naturalness imputed to the disaster in the past" (LOPES, 2015, pp. 237). By "naturalizing" the disaster, it ceases to be perceived as a complex and multidimensional event (OLIVER-SMITH, 1999).

(15) Tubarão still does not sleep quietly. O Estado, Florianópolis, March 22. 1981, Collection of news on the flood of 1974 of the Historical Archive of Municipal Tubarão.

(16) Frasson (2011) also points out that in addition to cash donations, food, building materials, and machinery, among others, were also donated. 
This relationship between the municipality's history and the memory of the flood of 1974 is also associated with the construction of a local identity. Rossi points out that monuments are "signs of collective will", and are "fixed points in the urban dynamics", which are marked in modernity by destruction and demolition, accelerated transformations in the forms of use, results of real estate speculation. In this sense, memory presents itself as a founding element of the sense of place in the city, marking the historicity of spaces (ROSSI, 1995). This importance of preserving the past also appears as a way of maintaining identity (HEWISON apud HARVEY, 2001).

The identity of cities is built through the search for elements that differentiate and singularize them. In this way, there is an "explicitation of the marks or symbols of the place occupied or sought, in an anxiety of particularity that distinguishes it and that congregates inhabitants and tourists, more and more present in their daily life" (RECHIA, 2005, 57). This search for a mark of local identity can induce new spaces of urban renewal, through which the consolidation of the most emblematic landmarks is sought (RECHIA, 2005). The author agrees with Fernandes (2001, page 323 apud RECHIA, 2005, page 58) that there may be an "intentionalism in particularism."

In this sense, the memories of the flood of 1974, internalized in the history of the municipality, contribute to the construction of the local identity of Tubarão, marked by the singularity of confronting a disaster. In the first decade of the twenty-first century, these memories are continually (re) constructed to legitimize new actions and political demands, associated with notions of the city's resilience and the social construction of risk, as the discourses in local newspaper reports point out.

Concerns about a new flood, like the one in 1974, are still expressed in newspaper reports, such as in the March 2004 and March 2014 editions, when the disaster was 30 and 40 years old respectively. In these editions, in addition to the memories of the victims and the destruction caused by the waters, the need for actions to prevent new disasters is also reported, mainly through the use of specialists. In the edition of the Diário do Sul newspaper that had the 30 years of the flood on the cover, there are reports of "real chances of new floods" 17 and also "how to avoid a new tragedy". ${ }^{18}$ In the Notisul, in an edition of the same date, the cover headline also refers to the risk of a new disaster: "The risk of a new disaster gets bigger every day". ${ }^{19}$ Inside the same newspaper, the news items also announce: "A new tragedy can happen at any time" 20 and "There is still time to avoid further disasters". ${ }^{21}$ In the news items of both editions, the dangers of environmental degradation, the repetition of natural cycles and the need for new works, such as a new process of dredging the Tubarão River, are punctuated by expert reports.

On the 40th anniversary of the flood, in 2014, the cover of the Diário do Sul had the following headline: "Exactly 40 years ago, floods devastated Tubarão and the region", followed by the subheading "Actions to minimize the consequences of new floods exist, but are insufficient." 22 One of the columns of the newspaper stated that after the straightening and dredging of the Tubarão River, completed by DNOS in 1983, "nothing else has been done", reaffirming the dangers of a new catastrophe. ${ }^{23}$ In another columnist's text, the need to remember the flood to avoid new disasters is expressed: "If when the floods are remembered every year, it is already difficult to carry out works, imagine if the past is forgotten." 24

In the same year, the city of Tubarão received certification as a Resilient City of the United Nations Office for Disaster Risk Reduction. The campaign's website ${ }^{25}$ reports that, since 1974, the municipality's vulnerability to new floods has been increasing due to population increase and the

(17) TB: real chances of flooding. Diário do Sul, Tubarão, Mar 24. 2004, p. 03.

(18) How to avoid a new tragedy. Diário do Sul, Tubarão, Mar 24. 2004, p. 03.

(19) Risk of a new disaster gets bigger every day. Notisul, Tubarão, 24 Mar. 2004.

(20) New tragedy can happen at any time. Notisul, Tubarão 24 Mar. 2004.

(21) There is still time to avoid further disasters. Notisul, Tubarão, 24 Mar. 2004.

(22) Exactly 40 years ago, Tubarão devastated flood and region. Diário do Sul, Tubarão, Mar 24. 2014.

(23) BARREIROS, A. 40 years later. Diário do Sul, Tubarão, Mar 24. 2014, p. 02

(24) MATOS, R. Do not forget the flood. South Diary, Tubarão, Mar 24. 2014, p. 03

(25) Can be viewed in http://www.unisdr.org/campaign/resilientcities/Home/cityprofile/City\%20Profile\%200f\%20 Tubar\%C3\%A3o/\%3Fid\%3D2493 
occupation of areas at risk of landslides and flooding. On the same page, risk mitigation measures are mentioned, such as monitoring networks, the preparation of a Drainage Plan and a Contingency Plan, among others.

Through these news reports, it is perceived that memory becomes a means to ratify the importance of new demands and political projects, focused on actions to prevent and reduce damage in the event of floods. This memory of the flood of 1974 is associated with the perception of risk, understood here as socially constructed (BECK, 2010). In a society of risk, characterized by techno-scientific rationality, threats are perceived as being capable of being calculated and controlled through technical interventions (DOUGLAS, 1994; BECK, 2010). Thus, although there are suggestions about changes in the subjects' behavior, in the sense of combating environmental degradation, the dominant discourses emphasize the need for new works and interventions as a means of managing the risks of a new catastrophe.

\section{FINAL CONSIDERATIONS}

The initiatives presented herein should not be considered as the only policies of remembrance of the 1974 flood in the municipality of Tubarão. It should also be borne in mind that monuments and references may have divergent readings from those intended by their creators, pointing to other possible constructions and re-significations of the memory of the disaster.

The social construction of urban space involves the construction of referentials and identities. Memory, objectified in monuments and reproduced in actions, such as those foreseen in the Day of Remembrance of the Catastrophe, presents itself as a key element in this construction, revealing what and how must be remembered. At the same time, this construction - understood in the research presented here mostly as governmental initiatives - legitimizes demands and actions in the present and in the future, which also participate in the social production of space and are remodeled over time.

\section{BIBLIOGRAPHIC REFERENCE}

ALBEIRICE, P. Tubarão 74: A Catástrofe. Tubarão: Dehon, 1981. 107 p.

ASSUNÇÃO, V. K. de. Enchente de 1974 como drama social: relações entre percepção de risco, conflito e gentrificação. Ambiente \& Sociedade, São Paulo, v. 17, n. 4, p. 195-212, dez. 2014. Disponível em: $<$ http://www.scielo.br/scielo.php?script=sci_arttext\&pid=S1414-753X2014000400011\&lng=en\&nrm=iso $>$. Acesso em: 04 abr. 2017.

BECK, U. Sociedade de risco: rumo a uma outra modernidade. 1. ed. São Paulo: Editora 34, 2010. 367 p. BOSI, E. Memória e sociedade: lembranças de velhos. 6 ed. São Paulo: T.A. Queiroz, 1998. 484 p. CARGNIN, A. Tubarão: do primeiro centenário ao fim do milênio. Tubarão, SC: Dehon, 2000. 174 p.

CDL - Câmara de Dirigentes Lojistas. Tubarão 50 anos. 2016. Disponível em: <http://cdltubarao.com.br/ Livro\%2050\%20anos\%20CDL.pdf>. Acesso em: 15 mar. 2017.

CORREAA, R. L. Monumentos, política e espaço. Scripta Nova. Revista Electrónica de Geografía y Ciencias Sociales, Barcelona, v. IX, n. 183, 2005. Disponível em: <http://www.ub.edu/geocrit/sn/sn-183.htm>. Acesso em: 20 abr. 2015.

DANIELS, S.; COSGROVE, D. Spetacle and Text. Landscape Metephors in Cultural Geography. In: DUNCAN, J.; LEY, D. (Org.). Place/Culture/Representation. Londres: Routledge, 1993. p. 57-77.

DOUGLAS, M. Risk and Blame: essays in cultural theory. New York: Routledge, 1994. 323 p.

FEUERSCHUETTE, I. J. Uma direção para a vida. Tubarão: Reuter, 2004.

FRASSON, M. M. A enchente de 1974 em Tubarão-SC: a construção de um desastre natural. 2011. 130 f. TCC (Graduação) - Curso de História, Universidade do Extremo Sul Catarinense, Criciúma, 2011. 
FREIRE, C. Além dos mapas. São Paulo: SESC, Annablume, 1997. 317 p.

FREITAS, C. F. Vivências e evidências da enchente de 1974 em Tubarão. 2001. 34 p. Monografia (Especialização em História Local e Regional) - Universidade do Extremo Sul Catarinense, 2001.

HALBWACHS, M. A memória coletiva. São Paulo: Vértice/Revista dos Tribunais, 1990. 189 p.

HARVEY, D. Condição pós-moderna. 10. ed. São Paulo: Loyola, 2001. 349 p.

JELIN, E. (Org.). Las conmemoraciones. Madrid: Siglo XXI, 2002. 254 p.

JEUDY, H-P. Introduction à la quatrième partie. In: JEUDY, H-P. (Org.) Patrimoines em folie. Paris: Éditions de la Maison des sciences de l'homme, 1990. p. 249-250

LEFEBVRE, H. O pensamento marxista e a cidade. Póvoa de Varzim: Ulissea, 1972. 173 p.

LOPES, A. R. S. Desastres socioambientais e memória no sul de Santa Catarina (1974-2004). 2015. 383

f. Tese (Doutorado em História Cultural) - Universidade Federal de Santa Catarina, Florianópolis, 2015.

MACHADO, C. do C. Tubarão 1974: Fatos e relatos da grande enchente. Tubarão, SC: UNISUL, 2005. 203 p.

MAUCH, C. Introduction. In: MAUCH, C.; PFISTER, C. (Orgs.). Natural Disasters, Cultural responses: case studies toward a global environmental history. Plymouth: Lexington Books, 2009. p. 1-16.

NORA, P. Entre memória e história: a problemática dos lugares. Projeto História. Revista do Programa de Estudos Pós-Graduados em História e do Departamento de História da PUC-SP, São Paulo, v. 10, n. 7-28, dez.1993.

OLIVER-SMITH, A. What is a Disaster. In: OLIVER-SMITH, A.; HOFFMAN S. M. (Org.). The Angry Earth: Disaster in Anthropological Perspective. London: Routledge, 1999. p. 18-34.

PEET, R. A Sign Taken for History: Daniel Shays Memorial in Petersham, Massachusetts. Annals of the Association of American Geographers, v. 86, v.1, p. 21-43, 1996.

PFISTER, C. The monster swallows you. Rachel Carson Center: Munich, 2011. 23 p.

PIPER, I. Investigación y acción política en prácticas de memoria colectiva. In: VINYES, R. (Org.). EI Estado y la memoria: gobiernos y ciudadanos frente a los traumas de la historia. Barcelona: RBA, 2009. p. 151-172. POLLAK, M. Memória, esquecimento, silêncio. Estudos Históricos, Rio de Janeiro, v. 2, n. 3, p. 3-15, 1989. RECHIA, S. Espaço e planejamento urbano na sociedade contemporânea: políticas públicas e a busca por uma marca identitária na cidade de Curitiba. Movimento, Porto Alegre, v. 11, n. 3, p. 49-66, set./dez. 2005. ROSSI, A. A arquitetura da cidade. São Paulo: Martins Fontes, 1995. 308 p.

ROWNTREE, L.B.; CONLEY, M.W. Symbolism and the Cultural Landscape. Annals of the Association of American Geographers, v. 70, n. 4, p. 459-479, 1980.

SANTOS, M. A natureza do espaço: técnica e tempo, razão e emoção. 2. ed. São Paulo: Hucitec, 1997. 308 p. SEDREZ, L. F. Desastres socioambientais, políticas públicas e memória. In: NODARI, E. S.; CORREA, S. M. de S. Migrações e Natureza. São Leopoldo: Oikos, 2013. p. 185-202.

SILVA, H. R. da. "Rememoração"/comemoração: as utilizações sociais da memória. Revista Brasileira de História, São Paulo, v. 22, n. 44, p. 425-438, 2002. Disponível em: <http://www.scielo.br/scielo. php?script=sci_arttext\&pid=S0102-01882002000200008>. Acesso em: 30 mar. 2015.

SMITH, G. Planning for Post-Disaster Recovery. Washington, DC: Island Press, 2012. 456 p.

THEIS, L. Jeux et enjeux commémoratifs. Le Débat, Paris, n. 104, p. 35, mar.-abr. 1999.

TUBARÃO. Lei no 3.289, de 12 de maio de 2009. Institui o Dia Municipal de Memória da Catástrofe de 1974. 2009.

ULLBERG, S. La mémoire de la catastrophe et des lieux. In: ZENOBI, D.; ULLBERG, S.; SILVA, T. C. Traces: memoires et politiques des désastres en Amérique Latine. Paris: L'Harmattan, 2016. p. 17-35.

VELHO, G. A utopia urbana: um estudo de antropologia social. Rio de Janeiro: Zahar, 2002. 124 p.

VETTORETTI, A. História de Tubarão: das origens ao século XX. Tubarão, SC: INCOPEL, 1992. 426 p.

VIGH, H. Crisis and Chronicity. Ethnos, v. 73, n. 1, p. 5-24, 2008. 
WOORTMANN, E. F. Identidades e Memória entre Teuto-Brasileiros. Horizontes Antropológicos, Porto Alegre, v. 6, n. 14, p. 205-238, 2000.

ZICMAN, R. B. História através da imprensa: algumas considerações metodológicas. Projeto História. Revista do Programa de Estudos Pós-Graduados de História, São Paulo, n. 4, p. 89-102, 1985. 